\title{
K datování věteřovských keramických souborů na střední Moravě
}

\section{On the dating of Věterov ceramic assemblages in Central Moravia}

\author{
David Parma / Pavel Fojtík
}

\begin{abstract}
Abstrakt
Závěr starší a počátek střední doby bronzové patři na Moravě k těm pravěkým obdobím, u nichž dosud nebyly vyřešeny některé základní koncepční otázky. To je dáno především neuspokojivou strukturou a stavem publikace archeologických pramenů, a nikoliv nedostatkem badatelského úsilí, což názorně demonstruje řada studií Stanislava Stuchlíka věnovaných právě tomuto tématu. Stávající představy počítají v různých podobách s přežíváním věteřovské skupiny do stupně $B$, dosavadní sumarizace radiokarbonových dat ukazují i na možnost "dlouhé" chronologie věteřovské skupiny, tedy její současnost jak s únětickou, tak s mohylovou kulturou. Dvojice datovaných nálezových souborů ze sídlištních komponent, které jsou zde představeny, je sice jen skromným príspěvkem, přesto jsou indicií svědčící spíše proti představám o současnosti hlavních kulturních celkủ tohoto období.
\end{abstract}

\section{Klíčová slova}

střední Morava; starší doba bronzová; střední doba bronzová; sídliště; absolutní datování

\begin{abstract}
The end of the Early Bronze Age and beginning of the Middle Bronze Age belong to prehistoric periods in Moravia, in which some fundamental conceptual problems were not yet solved. This is mainly given by the unsatisfactory structure and stage of publication of archaeological sources, and not by insufficient research effort. This is demonstrated by numerous studies by Stanislav Stuchlik which are dealing with this topic. The existing theories take into consideration that the Věteřov Group survived in various forms until the stage B B. Previous summarisations of radiocarbon dates indicated the possibility of a "long" chronology of the Věteřov Group, i.e. its parallel existence with both the Únětice Culture and the Tumulus Culture. The two dated assemblages of finds from settlement components presented in this text are a humble contribution, but they rather speak against the idea of a parallel existence of the main cultural units of this period.
\end{abstract}

\section{Key words}

Central Moravia; Early Bronze Age; Middle Bronze Age; settlements; absolute dating 


\section{Vstupní předpoklady}

Závěr starší a počátek střední doby bronzové je pro moravskou archeologii dlouhodobě problematickým obdobím. Z hlediska klasických kulturně historických schémat je reprezentován středodunajskou mohylovou kulturou a věteřovskou skupinou (Stuchlik 1993; Stuchliková 1993), přičemž specifické terminologické označení druhé z nich odkazuje, že jde o nedílnou součást většího kulturního celku obvykle označovaného dle eponymních lokalit $\mathrm{v}$ různém pořadí jako Věteřov - Mad’arovce - Böheimkirchen, který se zformoval na Moravě, jihozápadním Slovensku a v Dolním Rakousku. Všechny dosavadní přehledové práce o tomto časovém úseku pracují primárně v mantinelech kulturně-historického paradigmatu. Podstatou metodického prŕstupu je přiřazení lokalit ke kultuře a následné mapování kultur v prostoru, variabilita hmotné kultury a jevơ v rámci kultur bývá vysvětlována téměř bez výjimky chronologicky, tedy jako náplň jednotlivých dílčích stupňů a podstupňů (za všechny Stuchlik 1993; Stuchliková 1993).

$\mathrm{V}$ posledních desetiletích se podařilo i ve středoevropských podmínkách postupně shromáždit velké množství absolutních dat, téměř bez výjimky radiokarbonových, která umožňují tyto koncepce a závěry nezávisle testovat. Výsledky, jakkoliv zatím nepočetné, ukazují napřič pravěkem velmi podobné trendy, které jen málo odpovídají vstupním představám. Několik nezávislých sumarizací dat pro neolit ukázalo, že základní kultury jsou skutečně konzistentní celky, ovšem jejich dílčí stupně jsou běžně současné a platí, že čím podrobnější je členění, tím hưře dopadá jeho konfrontace $\mathrm{s}$ absolutním datováním (Kuča et al. 2012; Trampota - Květina 2020). Jelikož kulturně historické paradigma neumí ze své podstaty smysluplně pracovat s řadou evidentně odlišných, ovšem zároveň současných jednotek, byla navržena terminologie pracující s pojmem keramická tradice (na úrovni kultury) a keramická skupina (na úrovni stupňů a fází; Trampota - Květina 2020, 192), což by mělo usnadnit budoucí hledání odpovídajících interpretačních schémat. Do značné míry analogický výsledek byl dosažen masivním datováním jihoněmeckých pohřebišt starší doby bronzové. Stupeň B A1, definovaný především na základě jehlic, v něm jako celek obstál, jeho podstupně B Ala a B Alb ovšem již nikoliv. $\mathrm{V}$ tomto případě je opět rozdíl spíše otázkou prostoru než času, tedy jde spíśe o vliv regionality, než chronologickou následnost (naposledy Massy Stockhammer 2020; Brunner et al. 2020).

Zdá se tedy, že nemalá část variability archeologických pramenů má jiné než chronologické příčiny a dosavadní představy bude třeba v řadě případo̊ modifikovat, a to za užití odlišného pojmového a interpretačního aparátu. A jak si v tomto ohledu stojí závěr moravské starší doby bronzové?

\section{Přechod starší a střední doby bronzové na Moravě, koncepce a absolutní data}

Aktuální koncepce vnitřního vývoje věteřovské skupiny v čase počítá s jejím nahrazením středodunajskou mohylovou kulturou na počátku střední doby bronzové pouze na jižní Moravě, a tedy s delším přežíváním věteřovské skupiny ještě v průběhu stupně B B na střední Moravě (Stuchliková 1993, 265; Stuchlik 1992, 25). Předpokládá se souběžný začátek v celé oblasti výskytu v plné návaznosti na únětickou kulturu, ovšem konec jejího vývoje nastává v různých regionech v různé době a na počátku střední doby bronzové je nutné na Moravě předpokládat chronologickou současnost dvou kultur věteřovské skupiny a středodunajské mohylové kultury (Stuchlik 1992).

Snaha o podepření takové koncepce absolutním datováním dosud nepřinesla kýžené 
výsledky. Původní, v jádru jednoduchá představa, že lze archeologickou lokalitu jednoznačně paušálně přiřadit ke kultuře a $\mathrm{v}$ rámci jejího třídění k příslušnému chronologickému stupni a následně pak fixovat její chronologické postavení sérií radiokarbonových dat, vedla aktuálně k představě „dlouhé chronologie“ věteřovské skupiny, trvající minimálně čtyři století, a to s dvoutřetinovým překryvem vůči pouze tři století trvající únětické kultuře. Podobný, minimálně stoletý časový překryv, pak pozorujeme i vůči mohylové kultuře (Peška 2020, 106; Rožnovský 2020). Takový výsledek je samozřejmě v ostrém protikladu k aktuálnímu kulturně-historickému konceptu, který umožňuje pracovat $\mathrm{v}$ rámci jediného regionu pouze $\mathrm{s}$ chronologickou následností kultur, a vyvolává pochybnosti o správnosti celé koncepce moravské doby bronzové, prrípadně o akceptovatelnosti radiokarbonových dat. $\mathrm{K}$ ještě jinému výsledku vedla sumarizace dat Zoju Benkovsky-Pivovarovou, která na jejich základě předpokládá existenci specifického prechodného horizontu A2/B1, jehož náplní je ovšem přežívání zejména sídlišt se starobronzovou keramikou ještě do stupně B B1 v dolním i horním Rakousku i v jižních Čechách (Benkovsky-Pivovarová - Stadler 2019, 48-51, Abb. 1)

Práce s většími soubory radiokarbonových dat není samospásná, má svá pravidla, limity a dobře popsatelná úskalí. $\mathrm{V}$ př́ípadě konkrétního případu moravské doby bronzové lze příčiny problémů shledávat $\mathrm{v}$ zásadě dvě: málo poučený přístup k radiokarbonovému datování ze strany všech odběratelů vzorků a evidentně nevyhovující vstupní teoretický koncept jejich zpracovatelů.

První okruh problémů je logickým důsledkem postupného vývoje metodik radiokarbonového datování a jen velmi pomalého zavádění př́slušných standardů, ve východoevropském prostředí navíc umocněného dlouho malým počtem dat díky jejich finanční nedostupnos- ti. Základním problémem je především publikace dat bez patřičných souvislostí, tedy bez př́slušných nálezových souborů, což obvykle neumožňuje kriticky zkoumat správnost kulturního a chronologického zařazení datovaných artefaktů. Další otázkou je pak sama souvislost datovaných předmětů a př́slušných nálezových souborů jimi datovaných, tedy otázka elementární kritiky pramenů, dosud jen málo řešená. V neposlední řadě se skrývají značná úskalí i v samotné volbě vzorků, nejobvyklejší formu zkreslení výsledků představuje datování uhlíků a s nimi spojený „efekt starého dřeva“ nebo specifická dieta ovlivňující výsledky datování kostí všežravců. Všechny tyto zdroje potenciálních šumů lze eliminovat pečlivým výběrem vzorků a situací s otevřeným publikačním sdílením příslušných celků.

Druhý okruh problémů je méně technický a více systémový. Jde totiž o to, co je vlastně cílem datování. Obvykle je totiž východiskem předpoklad, že je třeba nejprve nálezové soubory zařadit do archeologické kultury a nejlépe i chronologického stupně, a výsledné datum pak dává informaci právě o stáří příslušné kultury a stupně. Kámen úrazu ovšem může být v přiřazení nálezových souborů, ke kterému dochází někdy bez patřičné argumentace a často silně subjektivně; ostatně při kritickém přístupu takové zařazení někdy prakticky ani není možné. Zde je nutné preferovat spíše přístup odlišný, hledající na základě absolutních dat obecná pravidla variability $\mathrm{v}$ rámci archeologických pramenů, která mohou být ve výsledku jakákoliv - podobná konceptu archeologických kultur, nebo významně odlišná. Tedy, spíše než zkoumat datování staršího stupně únětické kultury na základě hrobového celku, je lepší se ptát na vztah konkrétního datovaného nálezového souboru k různým aspektům definice staršího stupně únětické kultury.

Jestliže jsou do souboru absolutních dat na vstupu vneseny výše popsané dílčí chyby, 
dochází při následném zpracování k sumarizaci jak dat, tak i jejich chyb, což nutně vede k následkům v podobě „rozmlžených kontur“, tedy $\mathrm{k}$ dlouhým překryvům kultur a dlouhým chronologiím. Takovou situaci není možné řešit ani rozdělením dat na „správná“ a „evidentně chybná“, tedy na data, která nám vyhovují, a na data nevyhovující, jejichž prostým odstraněním z dalších úvah se problém řeší. Krokem vpřed musí být zejména práce využívající pouze publikované nálezové soubory a vhodně kombinující absolutní data s typochronologickými rozbory za dodržování alespoň elementárních zásad chronometrické hygieny. První pokusy na tomto poli, zaměřené pouze na hrobové celky, přinesly výsledky do značné míry odlišné od sumarizacích velkých souborů dat, a ukazují spíše na „krátkou chronologii“ věteřovské skupiny bez větších přesahů ( ̌́abatová - Parma 2020, Fig. 6). $\mathrm{Na}$ tomto místě jsou publikovány spolu s příslušnými radiobarbonovými daty dva nálezové soubory ze sídlišt, které sice samy o sobě neposkytují zázračná koncepční řešení, umožňují ovšem komentovat některé dříve vyslovené závěry, a především představují publikačně zpř́ístupněné celky umožňující v budoucnu další práci.

\section{Kroměřiž-Hradisko 2006, obj. 544}

Pravěké opevnění známé jako Hradisko u Kroměříže, nacházející se dnes v místní části Kroměříž-Hradisko, přitahovalo pozornost řady moravských badatelů od konce 19. století. První moderně dokumentované výzkumy zde realizoval v letech 1949-1956 Václav Spurný (obr. 2). Plošně odkryl část polykulturního sídliště v superpozici s podobně polykulturním pohřebištěm, systémem řezů a sond „vzorkoval“ vnitřní opevněný areál a na dvou místech pak protnul relikt obvodového opevnění. Právě stratigrafie zjištěná v místě opevnění v řezu I/50 se stala základem $\mathrm{k}$ formulování tezí o věteřovském stáří spodní části hradby a pak především o plynulém pokračování zdejšího věteřovského osídlení do střední doby bronzové a jeho kontinuální přechod do protolužické kultury (Spurný 1982). Tento koncept byl opakovaně publikován, ovšem bez odpovídajícího materiálu a situací, dlouhodobě z různých důvodů badatelsky nedostupných. Revizi situací na lokalitě v této situaci umožnil poprvé až záchranný výzkum z roku 2006, kdy trasa nově budované cyklostezky příčně protnula celý opevněný prostor včetně fortifikace (obr. 2). Ta byla zkoumána formou postupně zužované sondy prohloubené až na dno prríkopu, prričemž všechny situace související s opevněním a osídlením mladší doby bronzové byly následně publikačně zpřístupněny (Mikulková - Parma 2010). Situace ze starší doby bronzové byly také komplexně zpracovány a vyhodnoceny, tato práce ovšem zůstala pouze v rukopisné podobě (Daňhel 2007). V posledních letech se badatelsky zpřístupnila jak dokumentace, tak i nálezové fondy z výzkumů Václava Spurného, důsledná konfrontace poznatků z obou akcí je ovšem úkolem do budoucna.

Řezy fortifikací z 50. let a z roku 2006 jsou situovány 64 metrů od sebe a zachycují podobné situace (obr. 3), zásadní rozdíl je ovšem v jejich dochování. Václav Spurný zkoumal v sondě I/50 jak situace zahloubené do podloží, tak i dochovanou nadzemní část valu; v roce 2006 byly dokumentovány již pouze situace do $1 \mathrm{~m}$ nad úrovní podloží, nebot v těchto místech byl relikt hradby recentně odstraněn. V obou Spurného řezech je zachycen výrazný žlab K1 (Spurný 1954, obr. 1, 2), zasahující jako jediná součást fortifikace výrazněji do úrovně podloží. Ten je vzhledem $\mathrm{k}$ rozměrům a $\mathrm{k}$ analogické vzdálenosti od hrany př́íkopu možné ztotožnit se žlabem obj. 527 odkrytým v roce 2006, který je v superpozici s objektem 544, což je běžná zásobní jáma (obr. 3). Dle terénní situace je žlab 527 velmi pravděpodobně mladší, v každém případě se ovšem běžný sídlištní objekt 


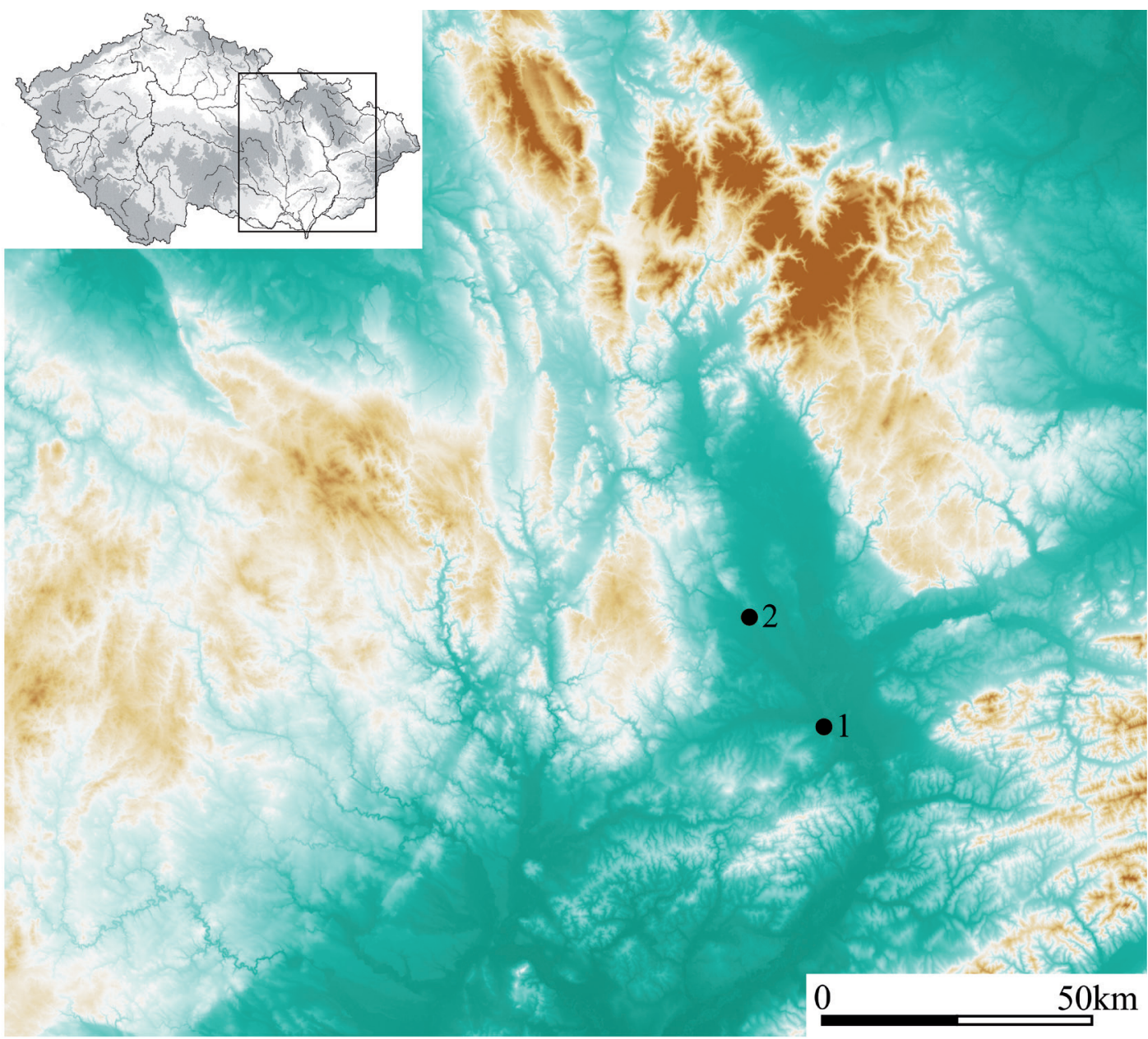

Obr. 1. Poloha lokalit Kroměříž-Hradisko (1) a Držovice (2).

Fig. 1. Localisation of the sites Kroměřiž-Hradisko (1) and Držovice (2).

544 př́mo v prostoru fortifikace s její funkcí prostorově vylučuje a musí být nutně starší, stejně jako objekt s hrobem $\mathrm{H}$ a věteřovskou keramikou zjištěný $\mathrm{v}$ podobné stratigrafické poloze v sondě I/50. Spurný předpokládal, že žlab K1 je součástí nejstaršího opevnění superponujícího starší sídlištní jámu (Spurný 1954, 360-362). Datováním nálezového souboru z objektu 544 tedy dostáváme datum spolehlivě předcházející výstavbě vnějšího pásma fortifikace na Hradisku u Kroměříže.
Objekt 544 z Kroměříže-Hradiska představuje klasickou zásobní jámu lichoběžníkového profilu, narušenou pouze $\mathrm{v}$ hrdle supepozicí se žlabem obj. 527 (obr. 4). Z její výplně pochází velké množství běžných sídlištních nálezů včetně rozsáhlého souboru keramiky (celkem 852 ks; kompletní popis a vyobrazení viz Mikulková - Parma 2010, 207-209, obr. 11-16), jednotlivých zvířecích kostí a z úrovně 0,8 m nade dnem kompletního skeletu prasete. Mezi keramickými zlomky je vyšší podíl sekundárního 


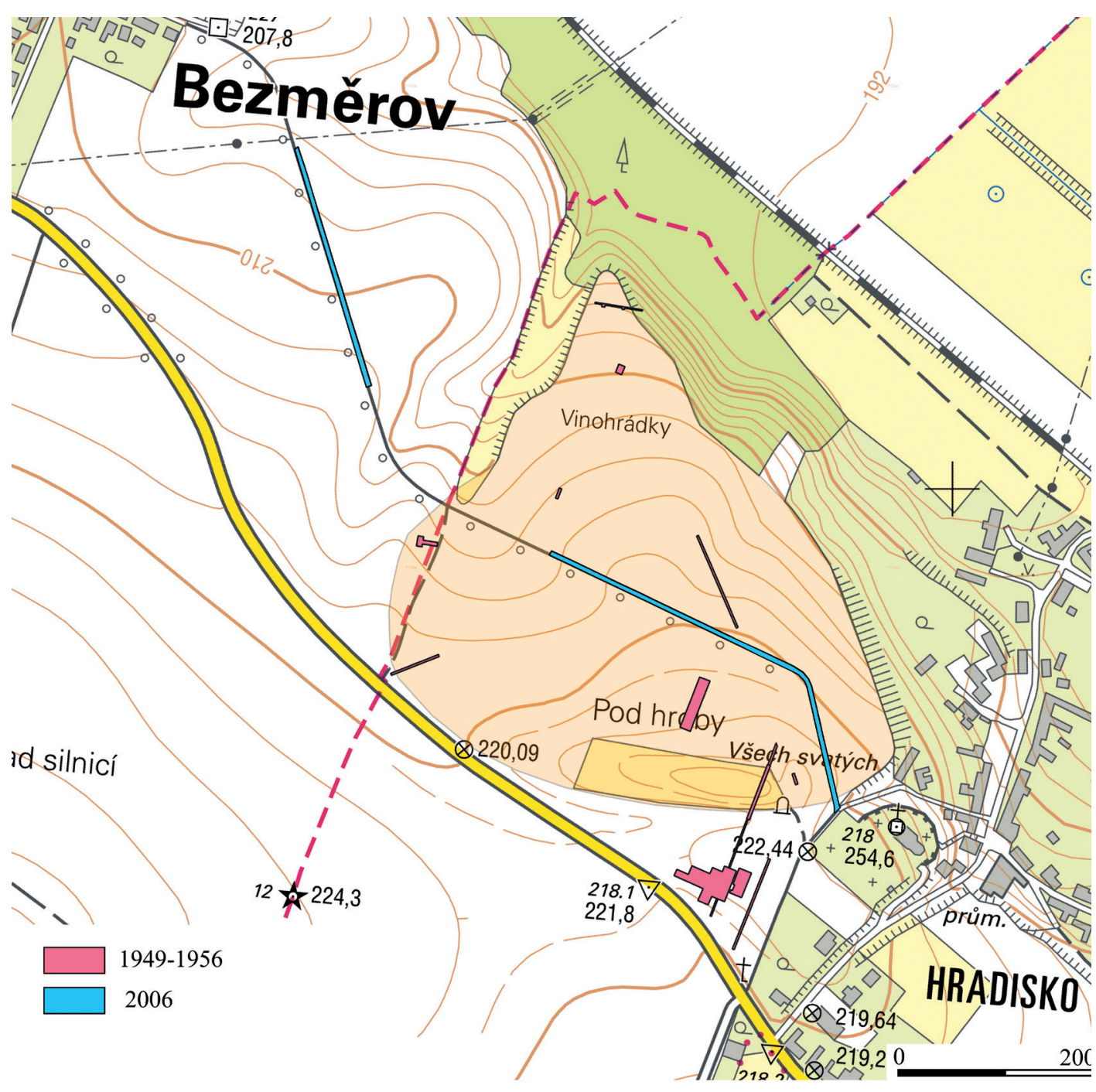

Obr. 2. Kroměříž-Hradisko. Přehled ploch zkoumaných v 50. letech 20. století (červeně) a v roce 2006 (modře).

Fig. 2. Kroměřiž-Hradisko. An overview of areas excavated in the 1950s (red) and in 2006 (blue).

odpadu, což dokládá množství rekonstruovatelných tvarů, celé nádoby ovšem chybí, soubor tedy nelze považovat za depozitum. Situace je vhodná pro datování - nálezový soubor je početný a dobře typologicky zařaditelný, počítáme se spíše rychlým zaplněním objektu, celý zvířecí skelet nemůže být intruzí a je stratigraficky mladší než (nerozlišené, ovšem početné) nálezy ze spodní části jámy. Keramický soubor ovšem nebyl kvantifikován a míra jeho fragmentarizace nebyla srovnána s dalšími soubory z lokality, nebyly rozlišeny mechanické ani přirozené vrstvy, nebyla řešena ani otázka stravy zvířete.

Nálezový soubor z výplně objektu je v podstatě kompletně a bezproblémově zařaditelný $\mathrm{k}$ věteřovskému keramickému stylu (obr. 5, 6). 


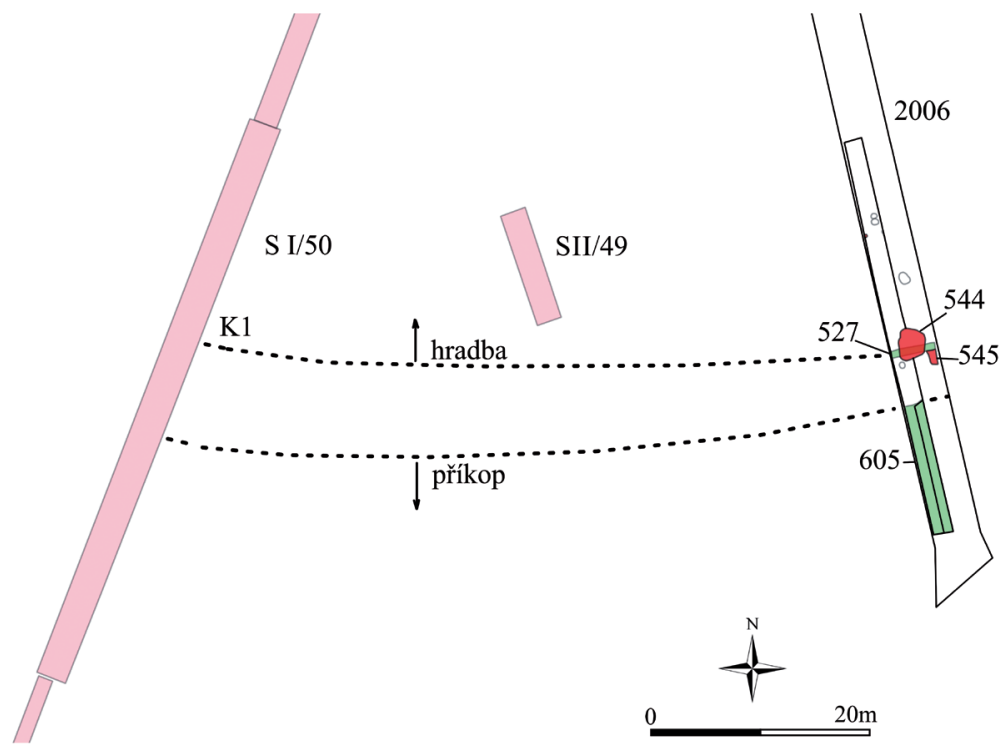

Obr. 3. Kroměříž-Hradisko. Detail situace s oběma řezy opevněním (I/50 a 2006), jejich rámcová synchronizace a interpretace, a poloha objektu 544.

Fig. 3. Kroměřiž-Hradisko. Detail of a context with two cross-sections through the fortification (I/50 and 2006), their general synchronisation and interpretation, and position of Feature 544.

Objevují se koflíky s výrazně vlnovitě profilovaným hrdlem (obr. 5: 1-3), soudkovité hrnky velkých rozměrů na nožkách i bez (obr. 5: 5-7), jednočlenné mísy s okrajem rozšířeným dovnitř (obr. 5: 17, 19) i na obě strany (obr. 5: 16, 20). Jako zlomek zásobnice je určitelná pouze část okraje (Mikulková - Parma 2010, obr. 13: 3) a drobný zlomek hrdla se šikmými záseky (obr. 6: 5), jinak kuchyňskou keramiku reprezentují především početné zlomky hrnců převážně plynule esovité profilace $s$ výčnělky pod okrajem (obr. 6: 8-10). Dosud nejdetailnější analýzy moravské věteřovské keramiky, založené především na početných souborech z jihomoravských Hodonic, vypracoval v plné návaznosti na práce Jany Stuchlíkové David Rožnovský (2015; 2019). V rámci jeho třídění lze soubor z objektu 544 tvarově zařadit do klasické fáze (dle Rožnovský 2015), přičemž podstatná je přítomnost vlnovitě profilovaných koflíků a soudkovitých hrnků s nožkami; amfory v celých tvarech dochovány nejsou, zlomky hrdel ovšem (obr. 6: 3, $4,6,7)$ ukazují spíse na profilace odpovídající nádobám klasického stupně. Mísy s prohnutým hrdlem jsou zastoupeny jediným netypickým kusem (obr. 5: 15), jinak zcela převažují mísy s rozšířeným okrajem (obr. 5: 16-22). Koflík s přeseky na lomu (obr. 5: 2) má dobrou analogii v objektu 18 z blízkého sídliště v Bezměrově, kde se objevuje ve společnosti nádob zcela věteřovského stylu (Spurný 1972, obr. 14: 1-4) a také evidentně infiltrovaného fragmentu výrazně mladší amforovité nádoby (Spurný 1972, obr. 14: 5). S vývojem poklasické fáze by snad mohla být spojována jen válcovitá hrdla (obr. 6: $1,2)$, u nichž ovšem není jisté, zda patří amforám. Specifikem na Hradisku je, oproti lépe publikovaným jihomoravským souborům, početný výskyt výzdoby provedené vpichy vyplněnými inkrustací. Jde vždy o horizontální linii, někdy 

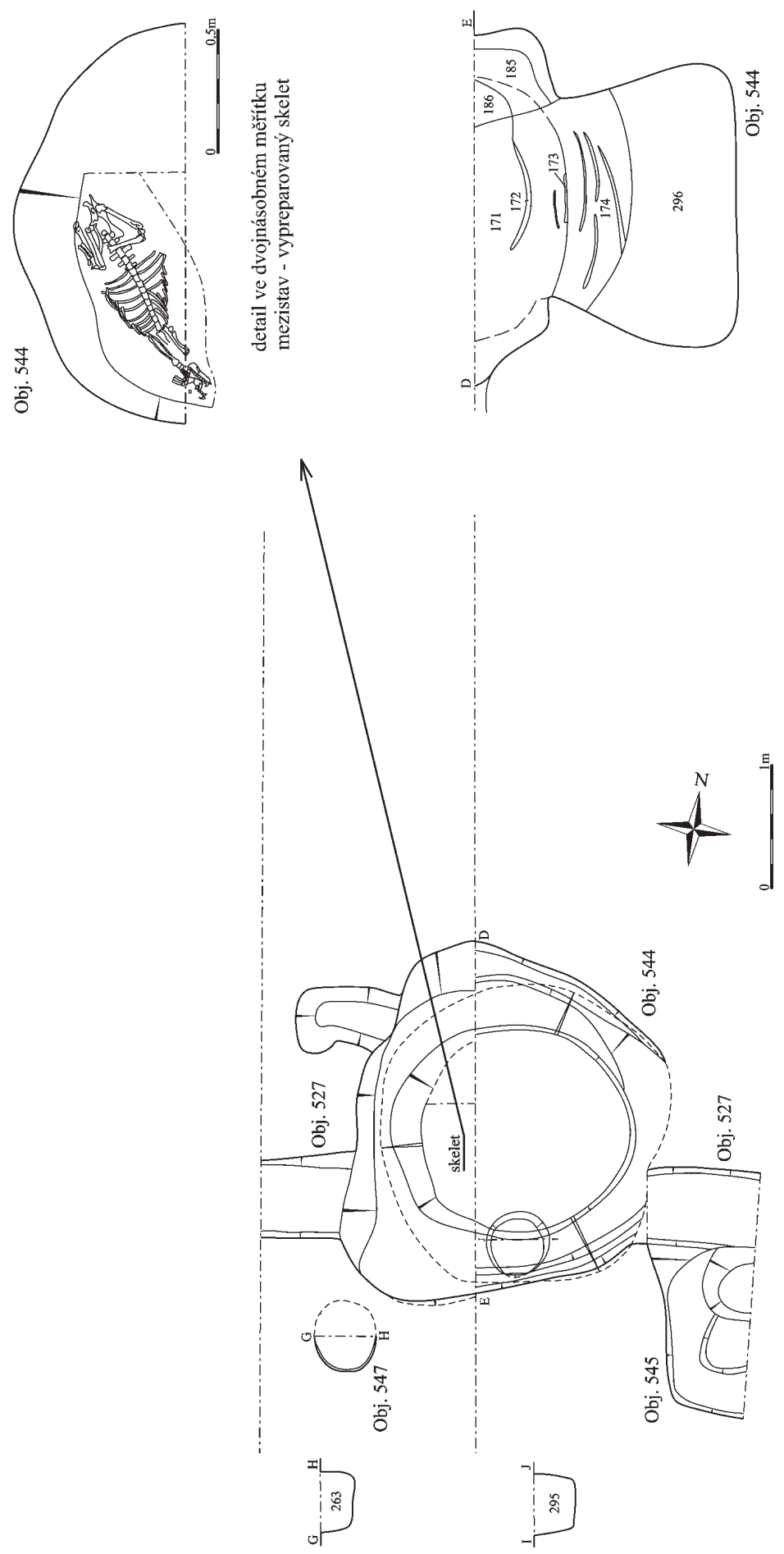

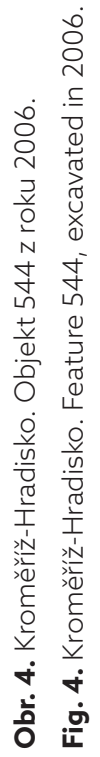



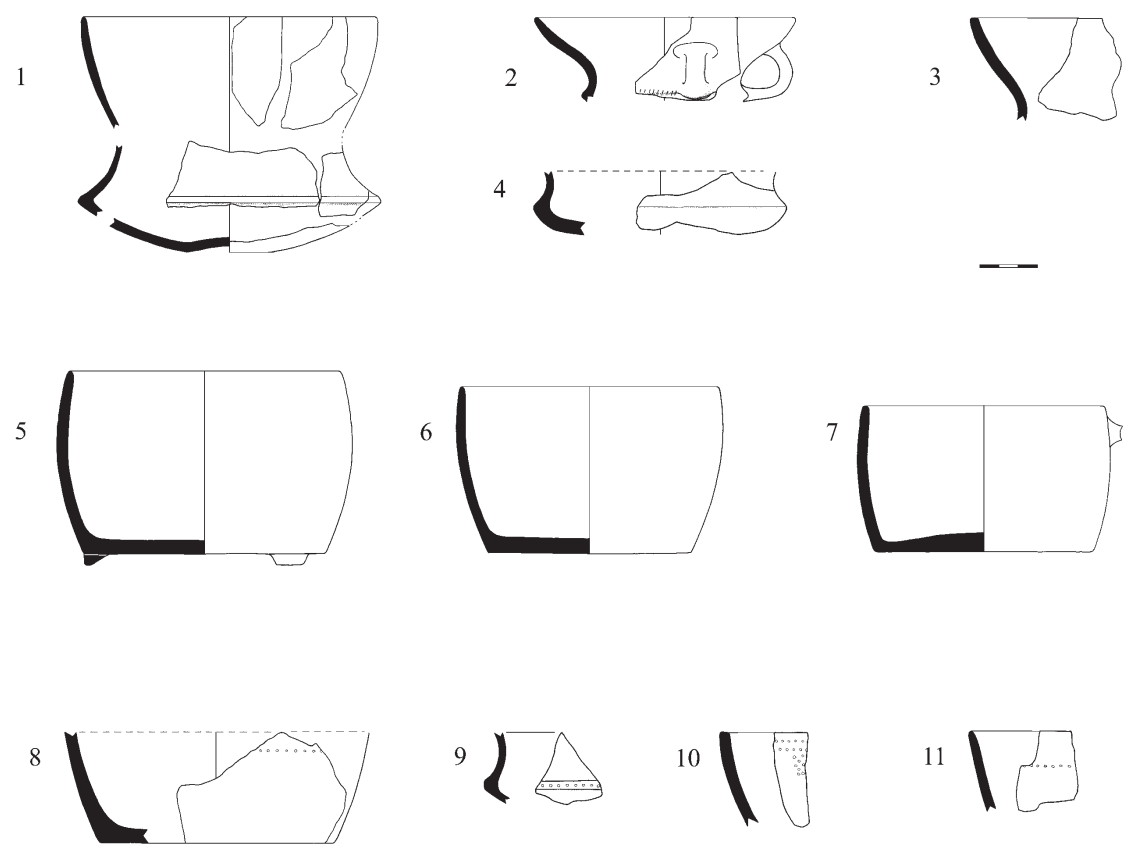

10
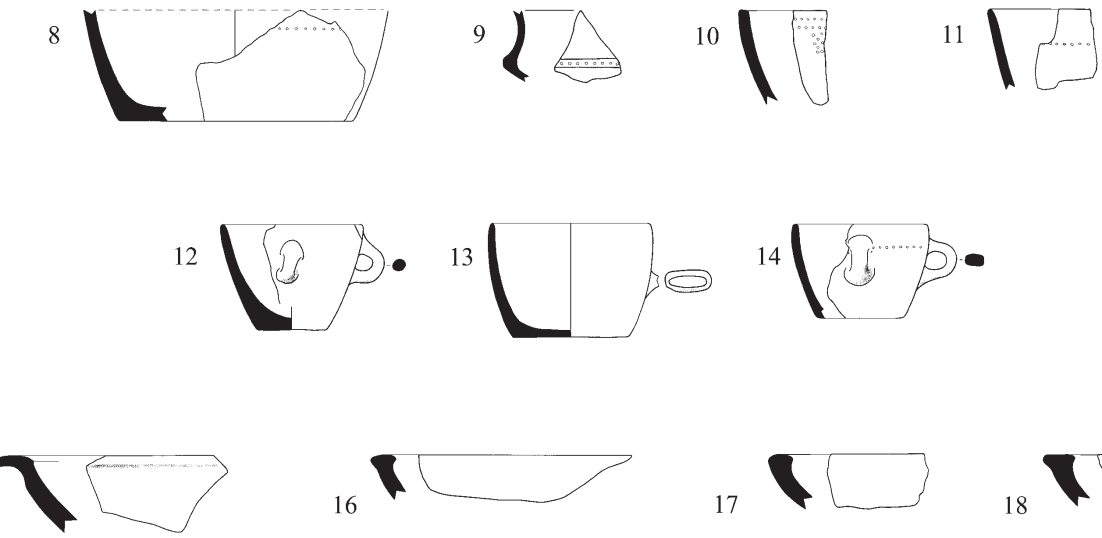

17

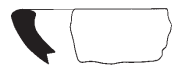

18

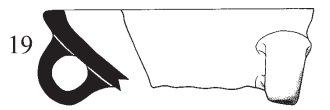

20
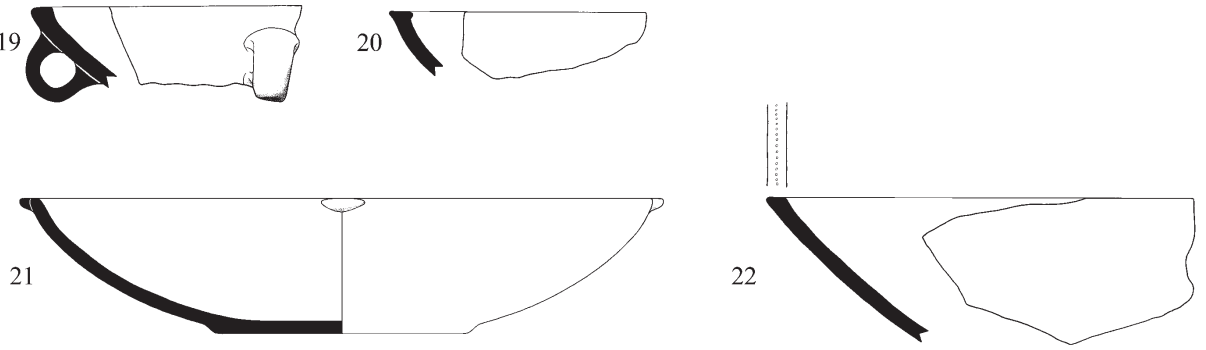

Obr. 5. Kroměříž-Hradisko. Výběr nálezů z objektu 544 z roku 2006.

Fig. 5. Kroměříž-Hradisko. Selection of finds from Feature 544, excavated in 2006. 
1

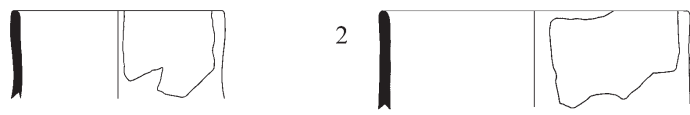

3

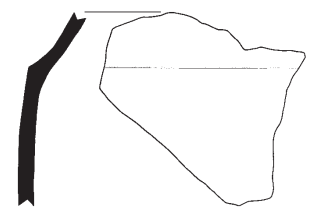

6

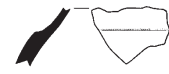

4

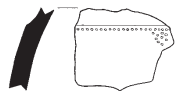

7

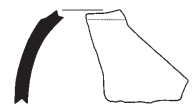

5

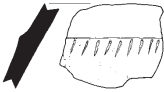

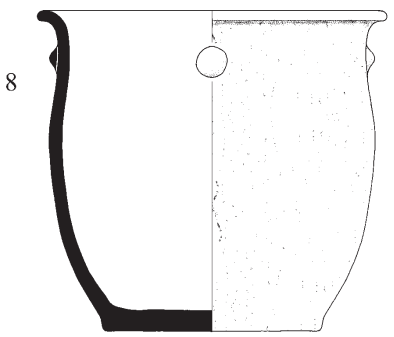

9

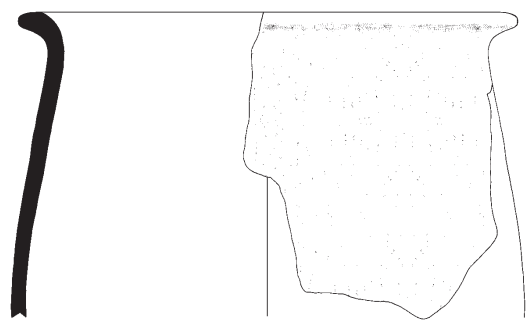

11
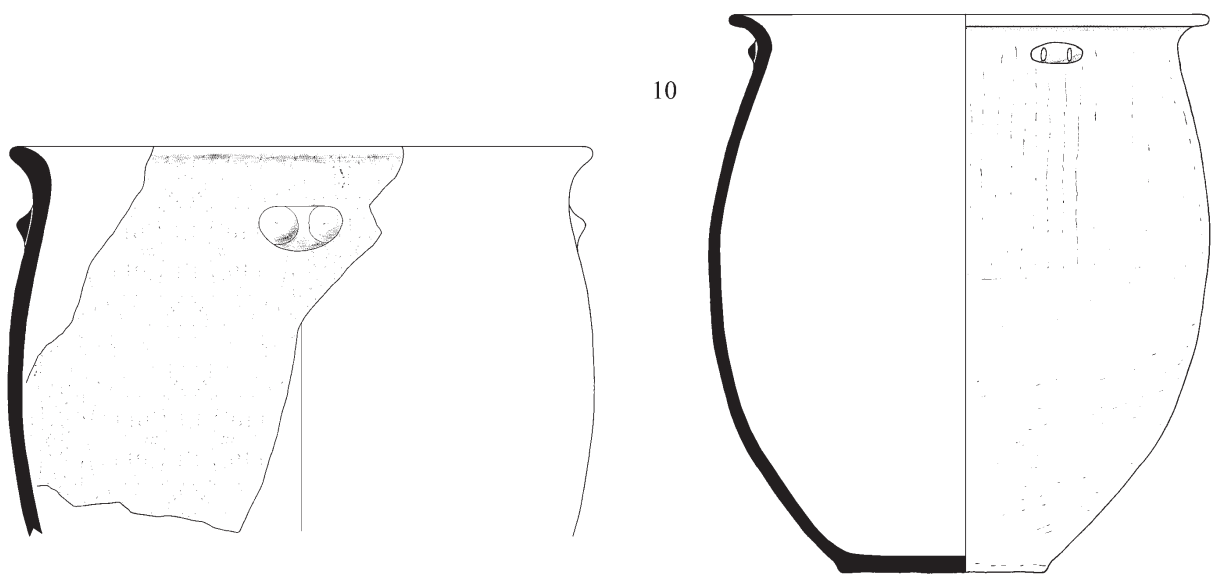

Obr. 6. Kroměříž-Hradisko. Výběr nálezů z objektu 544 z roku 2006.

Fig. 6. Kroměřiž-Hradisko. Selection of finds from Feature 544, excavated in 2006. 

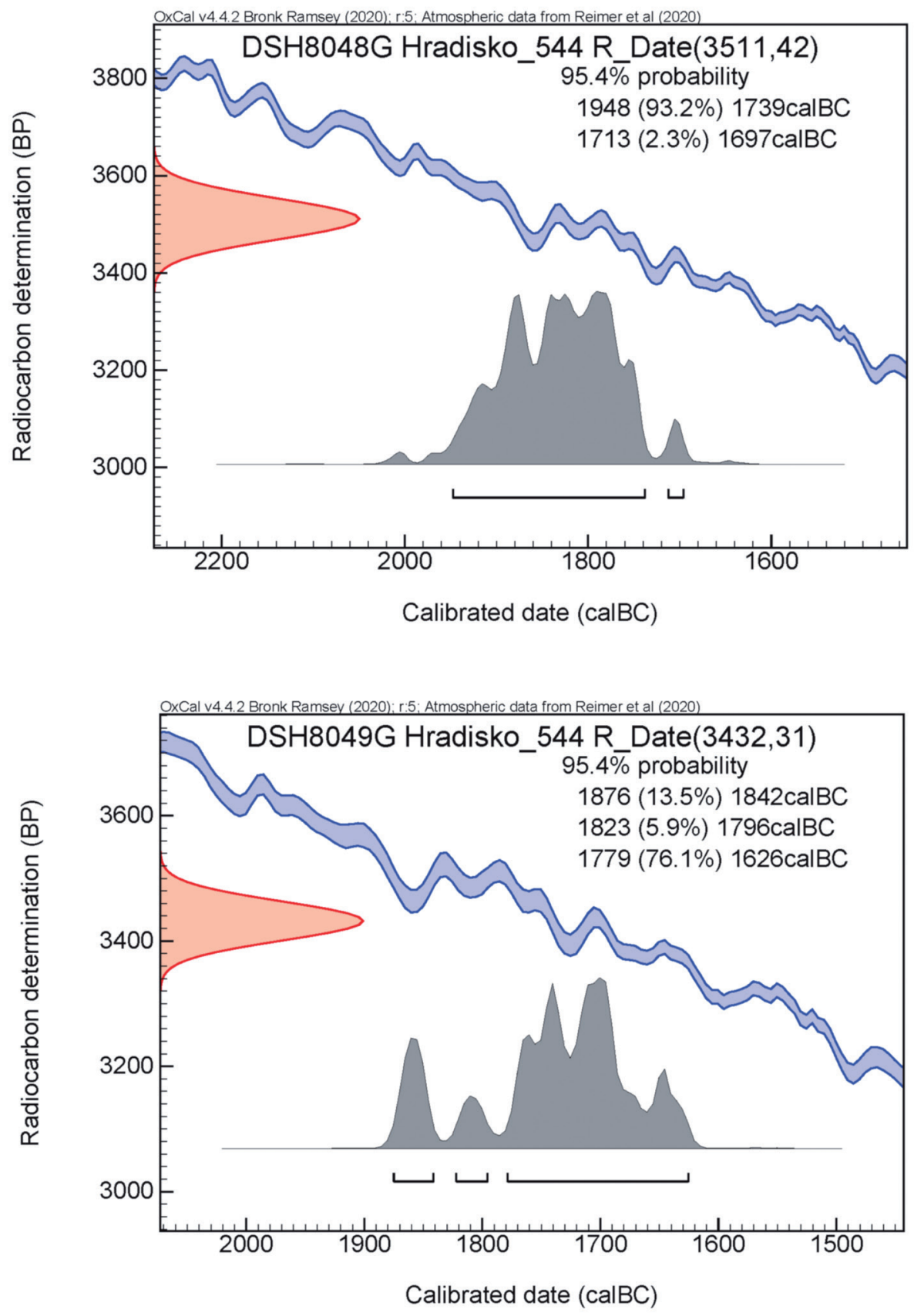

Obr. 7. Kroměřiž-Hradisko. Kalibrace dat z objektu 544 z roku 2006.

Fig. 7. Kroměříz-Hradisko. Calibration of dates from Feature 544, excavated in 2006. 
doplněnou rozetkami, aplikována je na koflících, hrncích, soudkovitých nádobách, mísách i amforách (obr. 5: 8-11, 14, 22; 6: 4). Tento typ výzdoby se objevuje $\mathrm{v}$ menším počtu kusů prakticky ve všech rozsáhlejších souborech věteřovské keramiky na Moravě (např. Hodonice; Rožnouský 2019, 84), v oblasti jižní Hané je však jeho výskyt evidentně běžnější a objevuje se i na více typech nádob (např. Tihelka 1960, 68-70).

Odebrány a v laboratoři CIRCE datovány byly dva vzorky zvířecích kostí (obr. 7). Datum z volné kosti krávy (metatarsus, bos primigenius) DSH8048G s hodnotou 3511 \pm 42 BP je nutno interpretovat spíše jako starší intruzi, nebot po kalibraci (Oxcal 4.4, křivka Intcal 2020; Reimer et al. 2020) vychází v intervalu $2 \delta$ 1948-1697 BC a v intervalu $1 \delta$ 1894-1753 BC. Datum z celého skeletu prasete (humerus, sus scrofa) DSH8049G reprezentuje zánikové stadium objektu, tedy dobu jeho zaplnění a uložení keramického souboru - objekty tohoto tvaru nemohly zůstat otevřené dlouhodobě, ke kolapsu stěn a následnému zaplnění spodní části dochází obvykle po první zimě. Hodnota $3432 \pm 31 \mathrm{BC}$, po kalibraci v intervalu $2 \delta$ 1876-1626 BC a v intervalu $1 \delta$ 1868-1646 BC, odpovídá $\mathrm{v}$ našich představách závěru stupně B A2 a je současná $s$ daty $z$ věteřovských hrobů v Boroticích (obr. 12); detailnější rozbor znesnadňuje vysoké rozmezí hodnot.

\section{Držovice - Pastviska 2014-2015, obj. 549}

Během záchranného výzkumu v poloze Pastviska bylo v letech 2014-2015 prozkoumáno celkem 74 zahloubených objektů z neolitu, pozdního eneolitu, starší a mladší doby bronzové, doby římské a raného středověku (Fojtik 2016; pro přehled dalších akcí v okolí Geislerová - Parma a kol. 2018, 219-221; obr. 8A). Rámcově do závěru starší či počátku střední doby bronzové lze datovat celkem pět objektů, čtyři menší jámy kruhového půdorysu a jednu větší neúplně zachycenou, další tři objekty lze zařadit do mladší doby bronzové.

Objekt 549 je jáma kruhového půdorysu a vakovitého profilu s průměrem ústí 1,2 $\mathrm{m}$ a max. průměrem 1,65/1,75 m o max. hloubce $0,9 \mathrm{~m}$. Výplně: k. 121 - středně ulehlá hnědá prachová hlína, hrudky mazanice ojediněle; k. 130 - tmavě hnědá prachová hlína (obr. $8 \mathrm{~B}$ ). Je superponován mladším objektem 550 nepravidelného tvaru o rozměrech $0,42 \times 0,63 \mathrm{~m}$ a hloubce 0,25 m, datovaným do mladohradištního období. Muzeum a galerie v Prostějově, inv. č. 285.342285.422 (obr. 8-10).

Objekt 549 je z hlediska základní kritiky pramenů pro absolutní datování nálezového souboru jen málo vhodný - jde sice o zásobní jámu pravidelného půdorysu s podhloubenými stěnami s předpokladem rychlého zaplnění, ovšem superponovanou plytkým nepravidelným objektem 550 z raného středověku. Velmi volný může být i vztah datovaného předmětu (dvě volné zviŕrecí kosti, navíc neurčené) k nálezovému souboru. Oproti tomu ovšem stojí sám nálezový soubor s rekonstruovanou amforou, nádobou s trny a s jehlicí i argument jednoduché rozlišitelnosti keramiky z doby bronzové a raného středověku, stejně jako skutečnost, že dvojice různých kostí poskytla zcela shodná data.

V každém případě obě data (obr. 11) ULA5849 s hodnotou 3320 \pm 30 BP, po kalibraci v intervalu $2 \delta$ 1680-1509 BC, a ULA5850 s hodnotou $3320 \pm 25 \mathrm{BP}$, po kalibraci v intervalu $2 \delta$ 1669-1511 BC, s nálezovým souborem dobře konvenují. Keramický soubor představuje prakticky nezdobená keramika, podobně jako v další prostorově blízké a pravděpodobně velmi podobně datované jámě 566 . Jediné tvarově rekonstruovatelné kusy jsou dvouuchá amfora s kuželovitým hrdlem (obr. 9: 4) a drobný kónický hrnek (obr. 9: 6), dobře identifikovatelné jsou ještě zlomky velké trojčlenné nádoby 
A

\section{A}
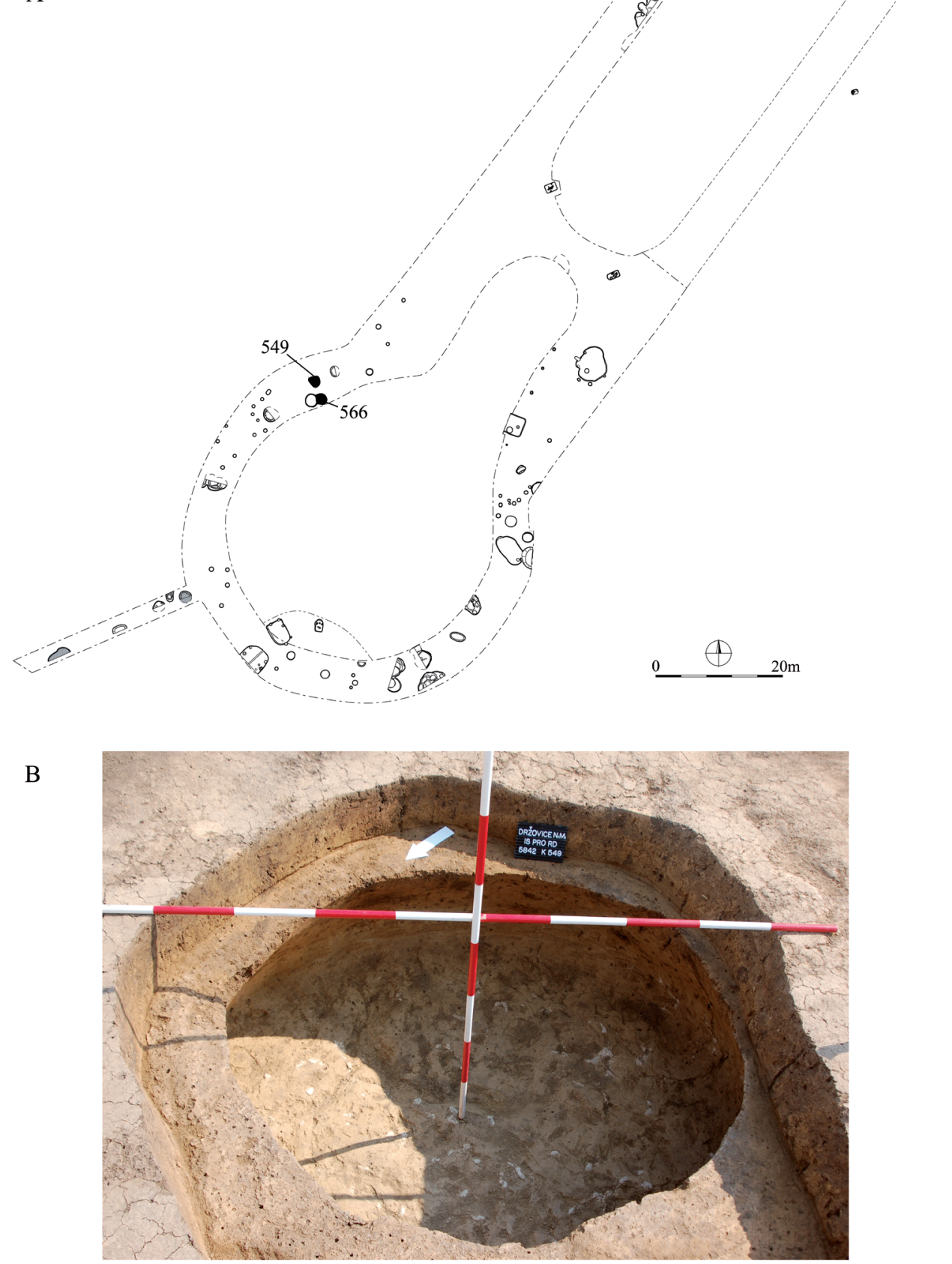

Obr. 8. Držovice (okr. Prostějov). Celkový plán výzkumu z let 2014-2015 (A) a superpozice objektů 549 (hlubší) a 550 (B).

Fig. 8. Držovice (Prostějov District). General plan of excavations in 2014-2015 (A) and superposition of features 549 (deeper) and 550 (B). 

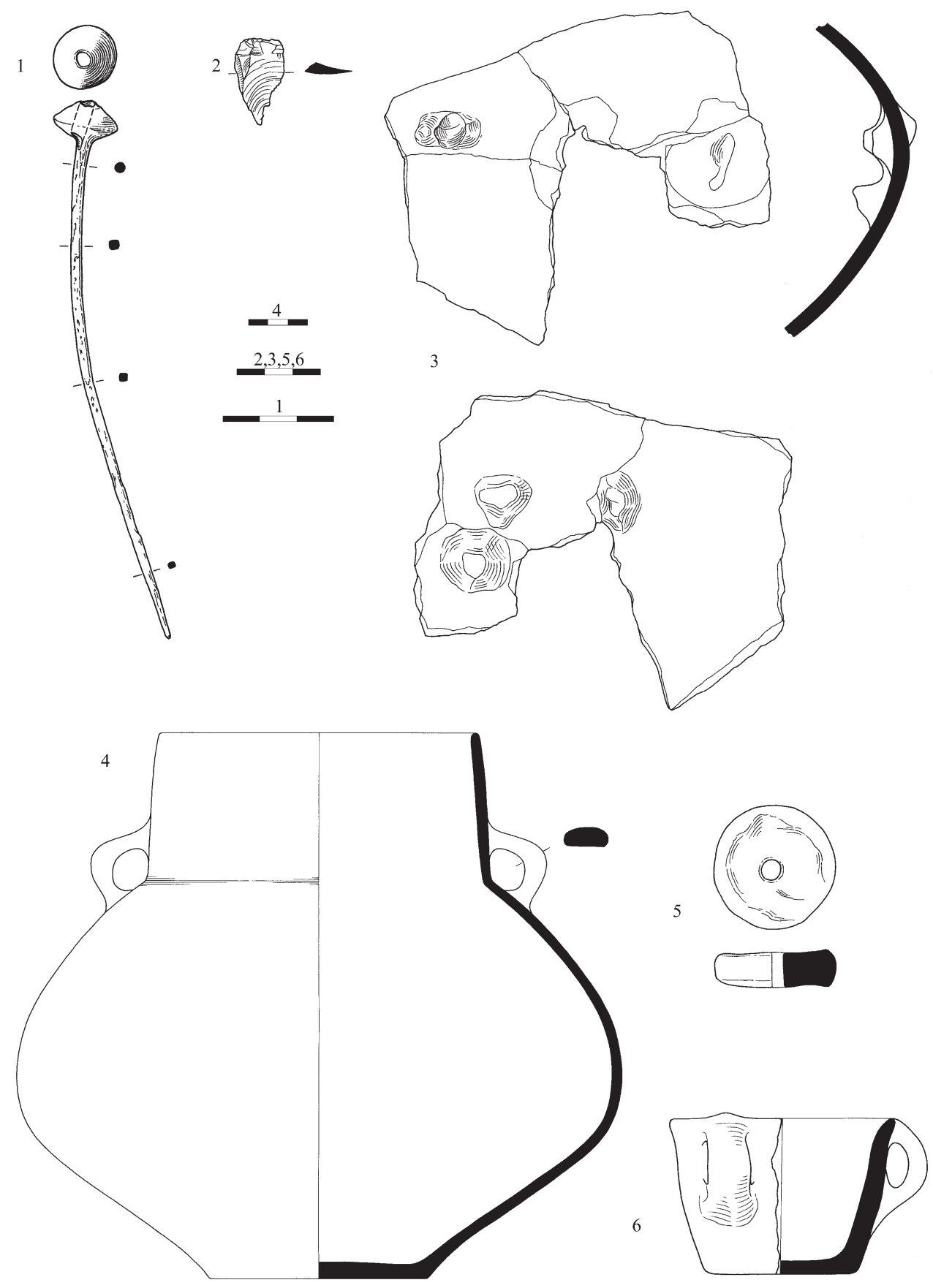

Obr. 9. Držovice (okr. Prostějov). Výběr nálezů z objektu 549.

Fig. 9. Držovice (Prostějov District). Selection of finds from Feature 549. 
$\mathrm{s}$ vnitřními trny, dost možná tvarově příbuzné věteřovské nádobě z Hodonic (Ondráček Stuchliková 1988, 23, obr. 4: 6). Také v poměrně početném souboru z blízkého objektu 566 schází keramika jednoznačně stylově věteřovská (s typickými tvary) nebo mohylová (s typickou, snadno identifikovatelnou výzdobou). Typochronologicky nejvýznamnějším artefaktem je jehlice s mírně prohnutou nezdobenou jehlou a dvoukónickou, nezdobenou a šikmo provrtanou hlavicí (délka $147 \mathrm{~mm}$, max. průměr hlavice $18 \mathrm{~mm}$; obr. 9: 1). Jde o přechodný typ k jehlicím typu Gajary, od nichž se liší absencí ryté výzdoby hlavice a tordování hrotu jehly, které se ovšem neobjevuje vždy (přehledně Novotná 1980, 43-47, Taf. 6). Jde patrně o první publikovaný kus z Moravy, vedle eponymní lokality na slovenském Záhoří se objevují v Dolním Rakousku a v mad’arském Zadunají, přičemž dle aktuální revize Zoji Benkovsky-Pivovarové vcelku není pochyb o jejich datování do počátku střední doby bronzové, tedy již do stupně B B1 (Benkovsky-Pivovarová - Chropouský 2015, 53-55).

Soubor doplňuje keramické kolečko (obr. 9: 5) a ostatní broušená industrie v podobě zlomku mlýnku (obr. 10: 2), dvou roztíračů (obr. 10: $3,4)$ a vybroušené kamenné čepele (obr. 10: 1), tedy artefakty informačně zajímavé, ovšem z typochronologického hlediska irelevantní.

Z Pastvisek dosud pocházejí ze sledovaného časového úseku pouze nálezové soubory klasifikovatelné stylově jako věteřovské (vedle výše popsaných ještě další dvojice objektů z výzkumu 2014-2015, viz obr. 8), naopak přesvědčivé soubory jasně stylově „mohylové“, tedy odpovídající zdobeným nádobám staršího a středního stupně mohylové kultury na jižní Moravě (Stuchlik 2006, 188-204, obr. 152), které pocházejí např. i z polohy Díly odvrahoviční taktéž z katastru Držovic, zde zatím absentují. Spolehlivě jsou na Pastviskách díky výzkumu z let 20142015 zachytitelné až soubory ze závěru střední, a především z mladší doby bronzové (detailně k topografii osídlení Držovic včetně katalogu nálezů ze střední doby bronzové viz Fojtik 2014; Fojtik 2015, 67-85).

Soubor nezdobené keramiky $\mathrm{z}$ počátku střední doby bronzové z Držovic je jen obtížně klasifikovatelný $\mathrm{v}$ intencích jednotlivých keramických stylů - neobsahuje ani typické tvary věteřovské, ani typické tvary či výzdobu mohylovou, v podstatě jediným chronologicky lépe zařaditelným artefaktem je jehlice blízká typu Gajary. Dobrým pandánem je mu ovšem opakovaně publikovaný sídlištní soubor z Brumovic ve Slezsku z jam 1 a 5 , odkud pochází směsice prakticky shodně profilovaných dvouuchých amfor, koflíků a misek věteřovského stylu (Pavelčík 1957; naposledy též Kühnholz 2013, taf. 30, 31). Je ovšem třeba vzít v úvahu, že tato lokalita se nachází v geograficky a snad i kulturně zřetelně odlišném regionu.

\section{Závěr}

Objekt 544 z Hradiska u Kroměříže poskytl dvojici dat dobře využitelných ve dvou rovinách. Vzhledem k jeho poloze a kvalitě situace je nutné považovat datum DSH8049G po kalibraci v intervalu $2 \delta$ 1876-1626 BC jako terminus post quem pro stavbu vnějšího opevnění. To bude v budoucnu možné doplnit o data z výplně příkopu, což patrně definitivně fixuje stáří fortifikace; dosud je pouze jisté, že ze spodní části výplně příkopu pocházejí nálezy z počátku mladší doby bronzové (detailně Mikulková - Parma 2010, 210-221). I v prŕípadě, že vnější opevnění se sídlištěm starší doby bronzové vůbec nesouvisí, což je poměrně pravděpodobné, ovšem nelze o lokalitě přestat uvažovat jako o opevněném sídlišti, nebot nová geofyzikální prospekce prokázala existenci dalších dvou vnitřních ohrazení dosud neznámého stáří (Peška - Vránová eds. 2016, obr. 16), což 


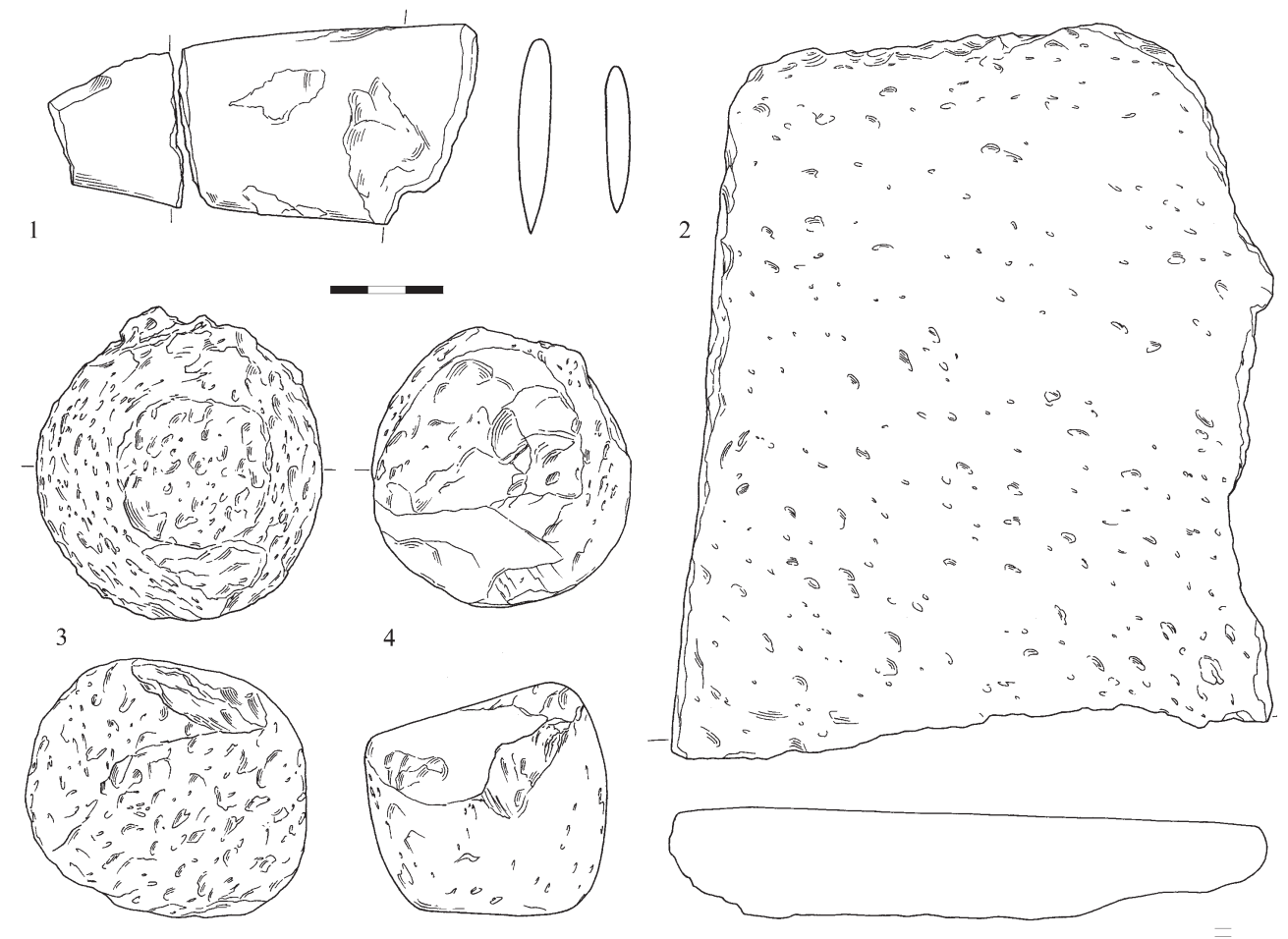

Obr. 10. Držovice (okr. Prostějov). Výběr nálezů z objektu 549, kámen.

Fig. 10. Držovice (Prostějov District). Selection of finds from Feature 549, stone.

velmi dobře odpovídá právě schématům starší doby bronzové. V obecnější rovině pak datum časově fixuje soubor keramiky jednoznačně věteřovského stylu, ztotožnitelný nejlépe s typochronologicky vyčleněnou klasickou fází, plně do rámce stupně B A2. Tento výsledek je triviální pouze dokud si neuvědomíme, že právě Hradisko u Kroměříže sloužilo Václavovi Spurnému k podložení představy o delším přežívání věteřovské skupiny na střední Moravě. Nyní je zřejmé, že většina starobronzových nálezových souborů odtud je stejně stará jako jejich jihomoravské protějšky a zůstává otázkou, zda půjde opravdu identifikovat spolehlivé soubory reprezentující na lokalitě mladší vývoj, který by byl jasně spojitelný s věteřov- ským keramickým stylem. Dosavadní kandidáti (zejména obj. 16 z Bezměrova; viz Spurný 1972, obr. 20) budí spíše pochybnosti a je zřejmé, že $v$ případě souvrství u valu jde o smíšené nálezy dvou zcela odlišných horizontů - závěru starší doby bronzové a závěru střední/počátku mladší doby bronzové (Mikulková - Parma 2010, 221-227). V každém případě je již delší dobu jisté, že Spurného představa o kontinuálním vývoji na Hradisku od starší doby bronzové k protolužické kultuře (např. Spurný 1982) je chybná. Ve středomoravském prostoru můžeme zcela bezpečně doložit řadu sídlišt s keramikou jednoznačně mohylového stylu (Fojtík 2015), která na Hradisku u Kroměříže chybí. $\mathrm{Na}$ prrítomnost jasně mohylových souborů na 

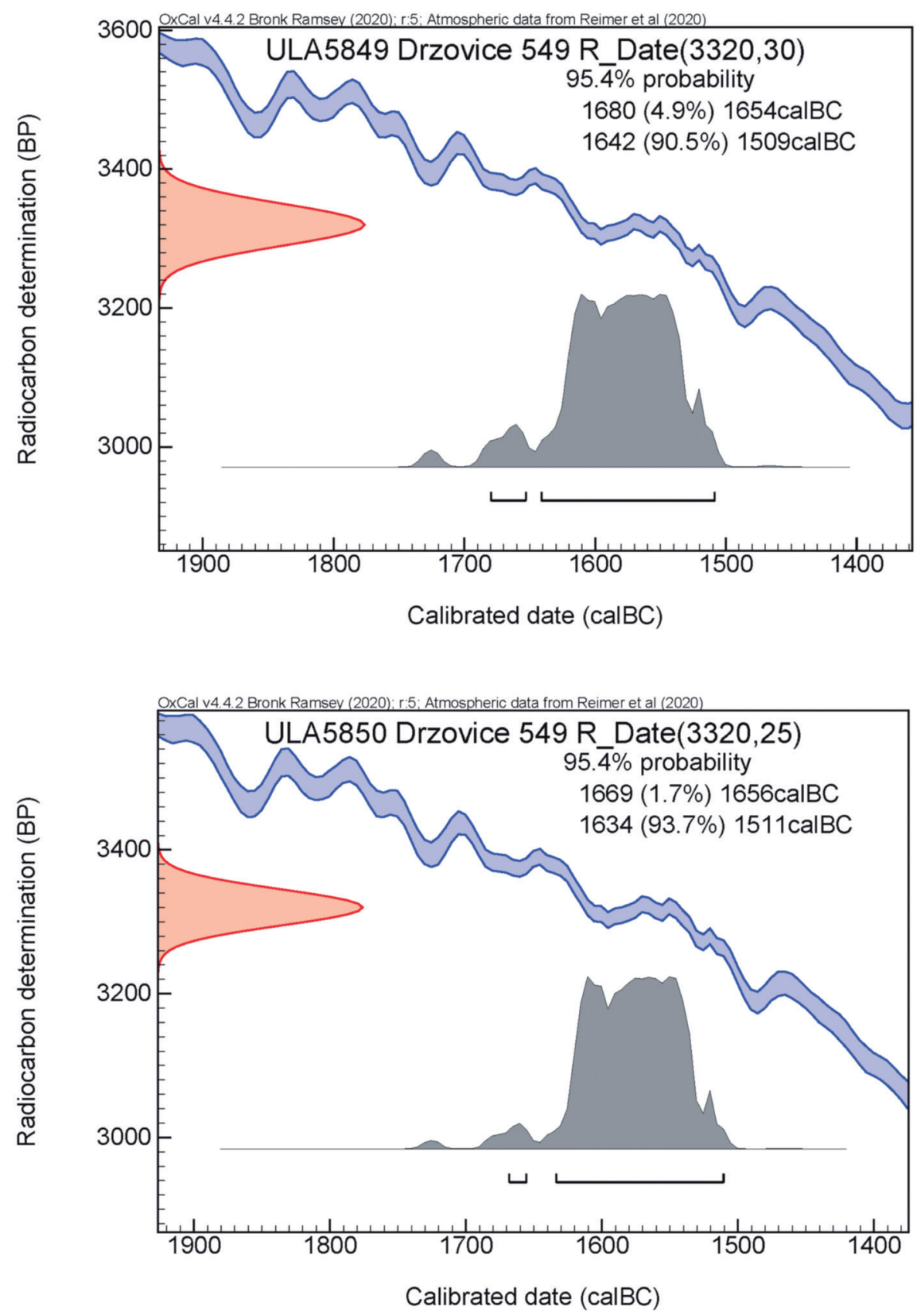

Obr. 11. Držovice (okr. Prostějov). Kalibrace dat z objektu 549.

Fig. 11. Držovice (Prostějov District). Calibration of dates from Feature 549. 


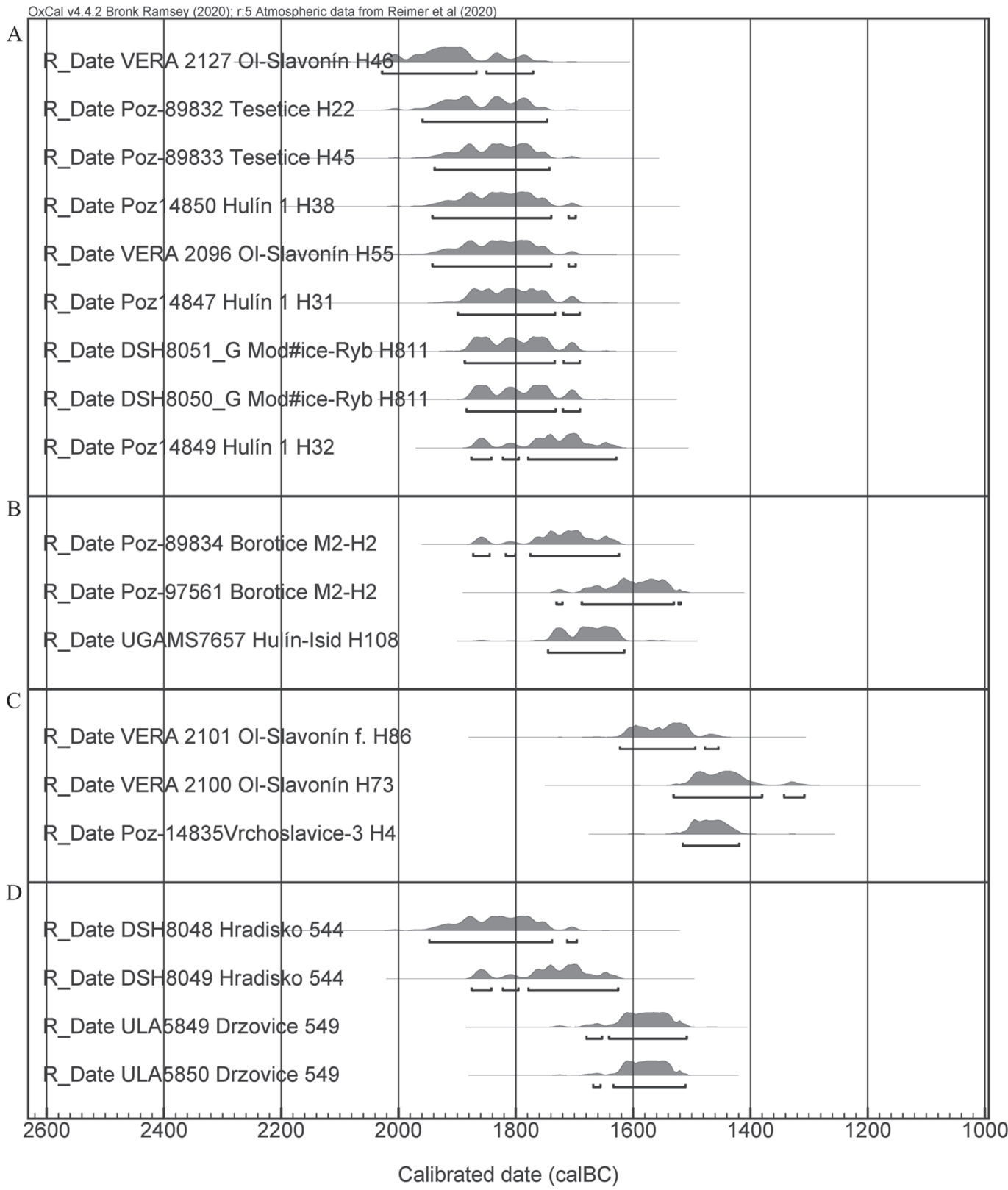

Obr. 12. Srovnání radiokarboniových dat z Kroměříže-Hradiska a Držovic s daty z publikovaných souborů z pohřebních komponent starší a počátku střední doby bronzové z Moravy. A - hroby únětické kultury, B - věteřovské hroby, C - hroby mohylové kultury (vše dle Šabatová - Parma 2020), D - sídlištní objekty z Kroměříže-Hradiska a Držovic.

Fig. 12. Comparison of radiocarbon dates from Kroměřiž-Hradisko and Držovice with dates of published assemblages from the Early and Middle Bronze Age funerary components in Moravia. A - graves of the Únětice Culture, B - graves of the Věteřov Group, C - graves of the Tumulus Culture (everything after Šabatová - Parma 2020), D - settlement features from Kroměříž-Hradisko and Držovice. 
střední Moravě ostatně ještě před komplexní publikací opakovaně upozornil již Stanislav Stuchlík (1998).

Obě téměř shodná data z objektu 549 z Držovic (v intervalu $2 \delta$ 1680-1509 BC, popř. 1669-1511 BC) při srovnání s dalšími daty z publikovaných celků z Moravy i s obecnou představou o absolutní chronologii v okolních oblastech jasně spadají již do počátku střední doby bronzové. Jsou současná s datem z hrobu 86 z Olomouce-Slavonína, o jehož řazení do stupně B B1 vcelku není sporu, a částečně i se sérií dat z dosud nepublikovaného sídliště tamtéž (Peška 2012, Abb. 10). Specifičnost těchto „nezdobených“ keramických souborů ovšem neumožnuje jasnou stylovou klasifikaci, jen těžko tedy mohou sloužit jako jasná indicie pro „přežívání věteřovské skupiny“ do stupně B B1 na střední Moravě. $\mathrm{V}$ jejich případě se ukazují slabiny přístupu založeného na apriorní kulturní klasifikaci nálezových souborů. Spíše než sledování věteřovské a mohylové kultury v čase a prostoru si lze představit, že

\section{Bibliografie}

Benkousky-Pivovarová, Z. - Chropovský, B. 2015: Grabfunde der frühen und der beginnenden mittleren Bronzezeit in der Slowakei. Nitra.

Benkovsky-Pivovarová, Z. - Stadler, P. 2019: Der bronzezeitliche „Übergangshorizont A2/B1“ aus der Sicht der Věteřov-Kultur, Pravěk NŘ 27, 43-74.

Brunner, M. - von Felten, J. - Hinz, M. - Hafner, A. 2020: Central European Early Bronze Age chronology revisited: A Bayesian examination of large-scale radiocarbon dating. PLoS ONE 15(12):e0243719.

Daňhel, M. 2007: Věteřovské objekty z výzkumu 2006 v Hradisku u Kroměříže. Rukopis diplomové práce uložený na FPF Slezské univerzity v Opavě. přínosnější může být jiný přístup, spočívající ve sledování prostorové a časové distribuce jednotlivých dílčích, dobře identifikovatelných fenoménů. V tomto případě sídelních komponent $\mathrm{s}$ keramikou jednoznačně věteřovského stylu, sídelních komponent s keramikou jednoznačně mohylového stylu, hrobových celků zařaditelných do stupně B B (které na Moravě obvykle žádnou jasně stylově zařaditelnou keramiku neobsahují) a souborů analogických Držovicím a Brumovicím. Jejich vzájemné vztahy nemusí být nutně pouze v rovině prosté chronologické následnosti ve smyslu „přechodného stupně“, mozaika vzájemných souvislostí může být daleko komplexnější.

Zdá se, že při dostatečně kritickém prrístupu k výběru a interpretaci datovaných situací, se potvrzuje spíše stará představa „krátké“ chronologie věteřovské skupiny na Moravě, přičemž při řešení problému jejího přežívání do stupně B B je především otázkou, zda takto datované nálezové soubory ze sídlišt ještě můžeme stylově klasifikovat jako věteřovské.

Fojtik, P. 2014: Pravěké a raně historické osídlení katastru obce Držovice, okr. Prostějov. Střední Morava $38,43-74$.

Fojtik, P. 2015: Mohylová kultura střední doby bronzové na Prostějovsku I. Katalog nálezů - svazek první. Pravěk Supplementum 30. Brno.

Fojtik, P. 2016: Držovice (k. ú. Držovice na Moravě, okr. Prostějov). Přehled výzkumů 57-1, 186-187.

Geislerová, K. - Parma, D. a kol. 2018: Výzkumy - Ausgrabungen 2011-2016. Brno.

Kuča, M. - Kovář́, J. - Nývltová Fišáková, M. - Škrdla, P. - Prokeš, L. - Vaškouých, M. - Schenk, Z. 2012: Chronologie neolitu na Moravě: předběžné výsledky. Přehled výzkumů 53(1), 51-64.

Kühnholz, D. 2013: Die Anfänge der Lausitzer Kultur in Mähren und der Slowakei. Universitätsforschungen zur prähistorischen Archäologie 227. Bonn. 
Massy, K. - Stockhammer, P. W. 2020: Testing Reinecke's chronology of the Early Bronze Age with radiocarbon dating. New evidence from southern Bavaria. Studia Hercynia XXIII/2, 22-35.

Mikulková, B. - Parma, D. 2010: Další pohled do osídlení Hradiska u Kroměříže - výzkum z roku 2006. In: Furmánek, V. - Miroššayová, E. (eds.): Popolnicové polia a doba halštatská. Nitra, 193-233.

Novotná, M. 1980: Die Nadeln in der Slowakei. Prähistorische Bronzefunde XIII/6. München.

Ondráček, J. - Stuchliková, J. 1988: Sídliště v Budkovicích a jeho postavení v rámci věteřovské skupiny. Památky archeologické LXXIX/1, 5-37.

Pavelčik, J. 1957: Sídliště lidu s nálevkovitými poháry a s keramikou věteřovského typu u Brumovic. Časopis Slezského muzea série B: Historia 6, 105-116.

Peška, J. 2012: Beispiele der absoluten Chronologie der Frühbronzezeit in Mähren und ihrer Verknüpfungen mit der Ägäis. In: Kujovský, R. - Mitáš, V. (eds.): Václav Furmánek a doba bronzová. Zborník k sedemdesiatym narodeninám. Nitra, 297-314.

Peška, J. 2020: Reineckes Erbe: Die absolute Chronologie der Frühbronzezeit Mährens - ein Diskussionsansatz. Studia Hercynia XXIII/2, 97-115.

Peška, J. - Vránová, V. (eds.) 2016: Věda rýče promluvila. Archeologické centrum Olomouc 1995-2015. Střípky. Olomouc.

Reimer, P. - Austin, W. - Bard, E. - Bayliss, A. - Blackwell, P. - Bronk Ramsey, C. - Butzin, M. - Cheng, H. - Edwards, R. - Friedrich, M. - Grootes, P. - Guilderson, T. - Hajdas, I. - Heaton, T. - Hogg, A. Hughen, K. - Kromer, B. - Manning, S. - Muscheler, R. - Palmer, J. - Pearson, C. - van der Plicht, J. - Reimer, R. - Richards, D. - Scott, E. - Southon, J. - Turney, C. - Wacker, L. - Adolphi, F. - Büntgen, U. - Capano, M. - Fahrni, S. - Fogtmann-Schulz, A. - Friedrich, R. - Köhler, P. - Kudsk, S. - Miyake, F. - Olsen, J. - Reinig, F. - Sakamoto, M. - Sookdeo, A. - Talamo, S. 2020: The IntCal20 Northern Hemisphere radiocarbon age calibration curve (0-55 cal kBP). Radiocarbon 62.

Rožnouský, D. 2015: Několik poznámek k chronologii moravské věteřovské skupiny na základě rozboru vybraných keramických tvarů. In: Bátora, J. Tóth, P. (eds.): Ked' bronz vystriedal med'. Zborník príspevkov z XXIII. medzinárodného sympózia „Staršia doba bronzová v Čechách, na Morave a na Slovensku“, Levice 8.-11. októbra 2013. Nitra - Bratislava, 51-66.

Rožnouský, D. 2019: Sídliště ze sklonku starší doby bronzové v Hodonicích (okr. Znojmo). Pravěk Supplementum 34. Brno.

Rožnouský, D. 2020: Frühe Bronzezeit und Stufe Br A3. Brauchen wir diese Stufe? Studia Hercynia XXIII/2, 116-123.

Spurný, V. 1954: Pohled do osídlení Hradiska u Kroměříže ve střední době bronzové. Památky archeologické XLV, 357-374.

Spurný, V. 1972: Sídliště starší a střední doby bronzové v Bezměrově u Kroměříže. Památky archeologické LXIII, 180-248.

Spurný, V. 1982: K časovému a kulturnímu postavení protolužického horizontu na Moravě. In: Południowa strefa kultury łużyckiej i powiązania tej kultury z południem. Kraków - Przemyśl, 121-133.

Stuchlik, S. 1992: Die Věteřov-Gruppe und das Entstehung der Hügelgräberkultur in Mähren. Prähistorische Zeitschrift 67, 15-42.

Stuchlik, S. 1993: Středodunajská mohylová kultura. In: Podborský, V. a kol.: Pravěké dějiny Moravy. Brno, 272-286.

Stuchlik, S. 1998: Nálezy mohylové kultury ze Smržic. Pravěk NŘ 7/1997, 245-254.

Stuchlik, S. 2006: Borotice. Mohylové pohřebišš z doby bronzové. Brno.

Stuchliková, J. 1993: Věteřovská skupina. In: Podborský, V. a kol.: Pravěké dějiny Moravy. Brno, 262-272.

Šabatová, K. - Parma, D. 2020: The Early to Middle Bronze Age transition as exemplified by Morava. Studia Hercynia XXIII/2, 124-139.

Tihelka, K. 1960: Moravský věteřovský typ. Památky archeologické LI/1, 27-135.

Trampota, F. - Kvétina, P. 2020: How do they fit together? A case study of Neolithic pottery typology and radiocarbon chronology. Archeologické rozhledy LXXII, 163-193. 


\section{On the dating of Vèterov ceramic assemblages in Central Moravia}

The current concept of internal chronology of the Věteřov Group takes into account that the replacement of this group by the Middle Danube Tumulus Culture at the beginning of the Middle Bronze Age took place only in South Moravia, whereas in Central Moravia the group still survived during the B B stage (Stuchliková 1993, 265; Stuchlik 1992, 25). We suppose that the Věteřov Group began simultaneously in its whole distribution area, following the Únětice Culture, but the end of its development occurred in various regions at various time. At the beginning of the Middle Bronze Age in Moravia, we must therefore suppose a synchronism of two cultural units - the Věteřov Group and the Middle Danube Tumulus Culture (Stuchlik 1992).

As a new contribution to this problem, the article introduces absolute dates from two settlement features located in Hradisko u Kroměříže and in Držovice. Feature 544 from Hradisko u Kroměříže, which contained a voluminous assemblage of Věteřov-style pottery, has yielded a pair of dates that can be used at two levels. With regard to location and quality of the find context, the calibrated date DSH8049G within the interval $2 \delta 1876-1626 \mathrm{BC}$ is to be considered a terminus post quem for the build-up of the external fortification. In the future, the dates from the ditch infill will be added, which probably definitely specify the age of the fortification; nowadays we know for certain that the lower part of the ditch infill has yielded finds from the beginning of the Late Bronze Age (in detail Mikulková - Parma 2010, 210-221). At a more general level, the the date fixes within the stage B A2 an an assemblage, which is best identifiable with the typologically and chronologically defined classical phase. This result appears trivial until we realize that Hradisko u Kroměříže was the argument on which Václav Spurný based his idea of a longer survival of the Věteřov Group in Central Moravia. Now it is evident that the majority of Early Bronze Age finds assemblages from this site are just as old as their counterparts from South Moravia. The question is whether it will indeed be possible to identify any reliable assemblages representing the more recent development of the site, which would be clearly associable with the Věteřov pottery style. The present candidates (especially Feature 16 from Bezměrov; see Spurný 1972, obr. 20) rather raise doubts and it is obvious that the sequence of strata near the rampart has yielded mixed assemblages of finds from two completely different horizons - the end of the Early Bronze Age and the end of the Middle Bronze Age/beginning of the Late Bronze Age (Mikulková - Parma 2010, 221-227). Anyway, for a long time already, it is clear that Spurnýs idea of a continuous development of Hradisko from the Early Bronze Age to the Proto-Lusatian Culture (e.g. Spurny 1982) is wrong. In the territory of Central Moravia, we know with absolute certainty the evidence of many settlement sites with Tumulus-Culture pottery (Fojtik 2015) which is absent on Hradisko u Kroměříže. It is to be remarked that Stanislav Stuchlík, still before the comprehensive publication, has repeatedly called attention to the presence of Tumulus-Culture finds assemblages in Central Moravia (Stuchlik 1998).

Feature 549 from Držovice contained an assemblage of typologically different undecorated pottery accompanied by a specific variant of a pin of type Gajary. The two absolute dates from animal bones within the interval 28 1680-1509 BC, or 1669-1511 BC respectively, when compared with other dates from the published assemblages from Moravia and with the general concept of absolute chronology in the surrounding regions, are already clearly assignable to the beginning of the Middle Bronze Age. They are parallel to the date from Grave 86 in Olomouc-Slavonín, which indisputably falls within the stage B B1, as well as to a series of dates from a still unpublished settlement on the same site (Peška 2012, Abb. 10). However, the specifics of these "undecorated" pottery assemblages do not enable to make a clear stylistic classification so that they cannot be used as an indisputable proof of the "survival of the Verteřov Group" until the stage B B1 in Central Moravia. Their example reveals the weaknesses of an approach based on a priori cultural classification of finds assemblages. Instead of following up the Věteřov 
Group and Tumulus Culture in time and space, we could rather choose a different approach based on the study of spatial and temporal distribution of individual partial, well identifiable phenomena. In this case, there are settlement components with clearly identified Věteřov-style pottery, settlement components with clearly identified Tumulus-Culture-style pottery, funerary assemblages assignable to the stage B B (these assemblages in Moravia usually do not contain any pottery of clearly identifiable style) and assemblages analogous to those from Držovice in Central Moravia and Brumovice in Silesia (Pavelčik 1957; Kühnholz 2013, taf. 30, 31). The relations between these components are not necessarily only at the level of mere chronological succession in the sense of a "transitional phase"; the mosaic of their interrelationships and functional links might be much more complex.

It seems that an adequately critical approach to the selection and interpretation of dated contexts rather confirms the older idea of a "short" chronology of the Věteřov Group in Moravia. Solving the problem of its survival until the stage B B, we mainly encounter the question of whether the finds assemblages from settlements, which are dated in this way, still can be classified as Věteřov-style finds.

\section{PhDr. Pavel Fojtík}

- Ústav archeologické památkové péče Brno, v.v.i. pracoviště Prostějov

Tetín 8, 79601 Prostějov, Česká republika

fojtik@uapp.cz

\section{Mgr. David Parma, Ph.D.}

- Ústav archeologické památkové péče Brno, v.v.i. Kaloudova 1321/30

61400 Brno, Česká republika

parma@uapp.cz 